\title{
IСТОРИЧНІ НАУКИ
}

\author{
DOI: https://doi.org/10.32839/2304-5809/2021-3-91-33 \\ УДК 94(477)
}

Баковецька O.O.

Миколаївська фрілія

Київського національного університету культури і мистецтв

\section{УКРАЇНСЬКІ ЖІНКИ У ВІЙНАХ ХХ-ХХІ СТОЛІТЬ}

\begin{abstract}
Анотація. Стаття присвячена висвітленню ролі та місця жінок у війнах XX-XXI століть: Першій, Другій світових війнах та російсько-українському конфлікту, що розпочався у 2014 рощі. В матеріалі визначено, що протягом вказаного періоду жінки завжди проявляли активну громадянську позицію і готові були нарівні 3 чоловіками відстоювати свою державу. В часи Першої світової війни жінки, в основному, приймали активну участь у діяльності благодійних товариств. Однак і на фронті, всупереч суспільній думщі, їх можна було побачити не лише серед медичної служби а й в якості бійців. Подібне явище не мало масового характеру, але доводило - жінки прагнули до дієвої участі у війні, визнанні їх прав на участь у вирішенні існуючих викликів та гендерної рівності із чоловіками. В Другій світовій війні жінки окрім забезпечення фрункціонування галузей народного господарства, військової промисловості в тилу, медичної служби, пліч о пліч із чоловіками відстоювали свою землю від зазіхань армій супротивників. В наш час, з моменту початку російсько-української війни, жінки знов виявили готовність не лише шляхом провадження волонтерської діяльності, а із зброєю в руках захищати свою Батьківщину. Участь жінок у війнах є одним із засобів посилення супротиву противнику, а розвиток гендерної рівності, в тому числі в армії, є вкрай важливим і абсолютно виправданим. Ключові слова: жінка, гендерна рівність, військовослужбовець, війна, благодійність, волонтерство.
\end{abstract}

Bakovetskaya Olga Mykolayiv Branch of Kyiv National University of Culture and Arts

\section{UKRAINIAN WOMEN IN THE WARS OF THE XX-XXI CENTURIES}

Summary. The article is devoted to the role and place of women in the wars of the XX-XXI centuries: the First, Second World Wars and the Russian-Ukrainian conflict that began in 2014. The material states that during this period women always showed an active civil position and were ready to defend their state on an equal footing with men. During the First World War, women mainly took an active part in the activities of charitable societies: raising funds for the army, preparing food, treating, supporting the wounded, helping displaced persons and prisoners of war, sewing clothes for the military, participating in mobilization activities. However, at the front, contrary to public opinion, they could be seen not only among the medical service but also as fighters. And women-military did not concede neither in courage, nor in military skill to men-military. Such a phenomenon was not widespread, but it proved that women sought to participate effectively in the war, recognizing their right to participate in addressing existing challenges and gender equality with men. In World War II, in addition to ensuring the functioning of the national economy, the military industry in the rear, and the medical service, women side by side with men defended their land from the encroachments of enemy armies. In our time, since the beginning of the Russian-Ukrainian war, women have once again shown their readiness not only to volunteer, but to defend their homeland with weapons in hand. In recent years, the number of women in the Armed Forces of Ukraine has increased significantly. As a result of the reform of the Armed Forces on the principles of genderization of NATO structures, the legal and regulatory framework of the issue has changed. In accordance with the adopted regulations, the rights of women in the Ukrainian army were equated with the rights of men. The adoption of relevant programs and laws has certainly not solved all the problems related to the service of women in the army. But the direction in which to move is clearly outlined. The participation of women in wars is one of the means of strengthening resistance to the enemy, and the development of gender equality, including in the army, is extremely important and absolutely justified.

Keywords: woman, gender equality, serviceman, war, charity, volunteering.

Постановка проблеми. Завжди під словом “захисник” ми розуміємо чоловіків. Але ж не слід забувати й про жінок. Вони також в усі часи стояли поруч із чоловіками на захисті своєі Батьківшини. Однак більшість досліджень військової історії традищійно фокусують свою увагу на ролі чоловіків у процесах, пов'язаних із початком, перебігом і завершенням військових дій. Лише в останню чверть XX століття, в наслідок суспільних зрушень, питання жіночої історії починають дійсно актуалізуватися. Певною мірою, цому сприяло те, що у середині 1980-х років американська дослідниця Дж. Скотт ввела у науковий обіг термін «гендер». В останні десятиліття, тема, присвячена ролі жінок в соціальному розвитку суспільства, зокрема її військовий аспект, набуває особливої актуальності. Отже, дана стаття присвячена українським жінкам, які разом із чоловіками захищали Україну від ворогів.

Аналіз останніх досліджень і публікацій. Проблемою участі українських жінок в подіях Першої світової війни присвячено низку досліджень сучасних українських дослідників: М. Байдак [1], М. Гук [2], О. Павлишин [3] та інших. Визначенням ролі та місця українських жінок в роки Другої світової війни займаються: О. В. Стяжкіна [4], М. Ю. Шевченко та В. А. Гедз [5], I. І. Суховерська [6] та інші [7]. Науковці в своїх роботах спро- 
бували розглянути питання, позбувшись стереотипів нав'язаних радянською історичною наукою та максимально об'єктивно, на основі історичних джерел, відтворили особливості становища жінок в роки війни, їх внесок в справу захисту своєї рідної землі, визначили роль, яку вони відігравали у веденні військових операцій, підтримці фронту, наближенні перемоги та миру.

Виділення не вирішених раніше частин загальної проблеми. Окремою уваги з боку науковців сьогодні потребуе тема російсько-української війни, що розпочалась у 2014 році, зокрема висвітлення питання участі жінок у цьому конфлікті.

Мета статті - висвітлити основні напрями діяльності українських жінок під час війн XX-XXI століть, іх участь у вирішенні проблем війни та визначити роль, яку вони зіграли та продовжують відігравати у військових конфоліктах, виявити спільне та відмінне у поглядах, ставленні і діях жінок різних періодів відносно війни.

Виклад основного матеріалу дослідження. Під час Першої світової війни українські жінки не залишали своїх чоловіків. Всіма силами вони намагались їх підтримати, надати допомогу. Насамперед вони брали участь у роботі благодійних організацій, або самі ставали організаторами нових громадських і благодійних об’еднань. В містах, де були відсутні благодійні організації, жінки допомагали одноосібно. Так само, як учасниці благодійних та громадських організацій, вони збирали доброчинну допомогу, направляли на потреби армії дохід, що вони отримували від власної діяльності, працювали при шпиталях, польових кухнях, займалися підготовкою та постачанням продовольства, шили одяг, допомагали біженцям, переселенцям, займалися пропагандистською та мобілізаційною роботою. В зазначений період діяли: Український жіночий комітет допомоги пораненим воякам (Український комітет допомоги раненим жовнірам у Відні), Союз визволення України, відділ Українського Червоного Хреста, Жіноча громада, Український жіночий союз, Товариство допомоги населенню Півдня Росії, яке постраждало від воєнних дій, Союз українок-католичок, численні дамські комітети, жіночі спілки, товариства, клуби які створювались в багатьох містах України. Проблеми війни не обійшли стороною жінок в монастирях. Вони так само збирали кошти, шили одяг, амуніщію для військових, займалися продовольством та багатьма іншими питаннями, направленими на допомогу армії, пораненим, біженцям, ув'язненим [8, с. 103-120].

Діяльність українських жінок у благодійних, громадських організаціях, метою яких стала допомога армії та постраждалим внаслідок військових дій, охоплювала всю територію України. Це дев'ять губерній які входили до складу Російської імперії, та українські землі у складі АвстроУгорщини - Галичину та Буковину [9, с. 25].

Наприклад, ще від початку війни, при Одеському відділенні Червоного Хреста створили жіночий комітет, з метою відкриття, організації, утримання шпиталів для поранених військових. Комітет на чолі з Л. С. Сосновською за перший рік війни організував три шпиталі та відділ для лікування поранених військовослужбовців [10, с. 199]. Харківський Дамський комітет, починаючи з 1915 року проводив збір грошей на заку- півлю подарунків для військовослужбовців та підтримку пораненим. Київський Дамський комітет Червоного Хреста, на чолі із Є. С. Третяковою займався не лише справами постачання, але й опікувався пораненими військовими, що пройшли попередне лікування у шпиталях [11, с. 151].

$\mathrm{He}$ лише прояви благодійності, милосердя були притаманні українським жінкам в роки Першої світової війни. Також їх можна було зустріти i в окопах, де вони разом із чоловіками брали участь у військових операціях. Відома дослідниця гендерних студій Ольга Бежук, яка, насамперед займалась дослідженням діяльності галицького жіноцтва в роки Першої світової війни, в своєму інтерв’ю зазначила: «Поширеним е твердження, що перші жіночі загони були створені в Росії - батальйон смерті Бочкарьової або допоміжний жіночий корпус у Британії. Але вони були створені у 1917 році, коли це ініціював уряд. Брусилов i Керенський, побачивши депресивні настрої в армії, вирішили підключити жінок. У нас це було добровільно. Жінки самі зголошувалися воювати зі зброею в руках. Жіноча чота Січових стрільців-2 налічувала 33 жінки. За три роки до таких явищ у Європі. Загін входив у Січові стрільці-2. Усі дівчата, що були там, пройшли мілітарний вишкіл в організаціях «Січ», «Сокіл», «Пласт». Вони добре вміли стріляти, вести окопну війну. Коли ж дійшло до війни, австрійський уряд заборонив жінкам воювати. Такі жінки, як Олена СтепанівДашкевич, Марія Бачинська, Гандзя Дмитерко, Софрія Галечко та Ірена Кузь, пішли на війну. Ми повинні знати їх і пам'ятати про них» [12].

Саме Олена Степанів та Іандзя Дмитерко стали першими українськими жінками-добровольцями, які захотіли служити у війську не як сестри-милосердя, а саме як рядові стрільці, плічо-пліч з чоловіками. Ці дві жінки здобули повагу серед чоловіків-військових за свою звитягу, дуже швидко отримали ранг хорунжих, їх нагородили медалями за мужність. Під час бойових дій відзначилася Ірина (Ярема) Кузь, яка підірвала гранатами кулеметну позищію супротивника, захопила папери та карти московського штабу, взявши у полон кількох військових 3 ворожої армії. Інформація про цей приклад неймовірної мужності у 1915 році була опублікована в австрійському та американському часописах [13].

Не менш героїчно жінки проявляли себе в роки Другої світової війни. Безумовно, на жінок було покладено увесь тягар, пов'язаний із забезпеченням роботи тилових служб. На фрронті представнищі «слабкої статі», традищійно, виконували суто жіночі ролі - медична допомога, облаштування польових їдалень, мобілізаційні заходи. Водночас, історія має безліч прикладів неймовірної мужності жінок під час війни. Наведемо лише декілька прикладів. Нечепорчукова Мотрона Семенівна, яка закінчила Балаклійську акушерсько-сестринську школу, була санінструктором санітарної роти 100-го гвардійського стрілецького полку. Під час бойових дій на берлінському напрямку врятувала життя сімдесяти восьмим військовим, яких винесла 3 поля бою. Не зважаючи на поранення, продовжувала надавати медичну допомогу солдатам. Під час обстрілу поранених супротивником, її вдалось застрелити військового ворожої армії, який вів цей обстріл. За це iï нагородили орденом Слави 1-го ступеня, після 
чого М. С. Нечепорчукова стала повним кавалером ордена Слави. Пізніше, жінка була удостоєна нагороди Міжнародного комітету Червоного Хреста - медаллю імені Флоренс Найтінгейл. Не менш героїчно поводили себе на війні інші жінки: Пушина Феодора Андріївна - військовий фрельдшер, лейтенант медичної служби, Герой Радянського Союзу; Октябрська (Гарагуля) Марія Василівна - механікводій танка, Герой Радянського Союзу; Завалій Свдокія Миколаївна - єдина жінка - командир взводу морської піхоти, гвардії полковник; Павличенко Людмила Михайлівна- снайперка часів Другої світової війни, Герой Радянського Союзу [14] та багато інших представниџ «слабкої статі». Всі вони, разом із чоловіками, захищали свою Батьківщину, не поступаючись в мужності та самовіддачі.

В радянській історіографрії місце і роль жінки в роки Другої світової війни висвітлювалось досить однобічно. Впливали ідеологія, встановлені цензурою кліше. В сучасній українській історіографії підхід до питання поступово змінюеться. Все частіше з'являються дослідження в яких висвітлюються долі жінок, які були учасницями військових формувань ОУН та УПА; жінок, які вели підпільну боротьбу; тих, що потрапили до концтаборів, таборів для військовополонених, або залишалися на окупованих територіях і мали турбуватися про долю літніх людей, дітей, інвалідів, представників етнічних груп, які переслідувалися окупащійною владою з особливою жорстокістю; тих, що примусово були вивезені для робіт у Німеччині; жінок, які важко пращювали на військових підприемствах, в сільському господарстві, на будівництві військових укріплень. 3 метою привернути увагу суспільства до ролі жінки в Другій світовій війні, Український інститут нащіональної пам'яті у 2016 рощі розробив індрормаційно-просвітнищький проект «Війна не робить винятків. Жіночі історії Другої світової війни». Разом із телеканалом UA: Перший та Нащіональним музеєм історії України у Другій світовій війні було створено серію документальних роликів про жіночі долі в роки Другої світової війни [15]. Подібні заходи покликані відновити історичну правду, зняти роками сформовану заангажованість 3 цього питання.

Нова загроза, яка постала перед нашим суспільством у 2014 році - війна на Сході Україні, призвела до активізації громадянської позищії нашого народу. Зокрема, почала збільшуватися кількість військовослужбовищь у ЗС України. У 2008 рощі в українській армії проходило службу 1800 жінок. Станом на початок жовтня 2015 року, за словами начальнищі Управління комунікащії та преси Міністерства оборони України Оксани Гаврилюк, службу у Збройних силах України проходило близько 14,5 тис. жінок-військовослужбовців та 30,5 тис. працівників Збройних сил. 3 них - 938 жінок-військовослужбовців взяли участь у проведенні АТО, майже 2 тис. - офіцери, 35 жінок-військовослужбовців перебували на керівних посадах в Міноборони, Генштабі ЗСУ [16, с. 14-15]. Станом на березень 2020 року у ЗС України служить 29760 жінок: $902-$ старший офріцерський склад, 1090 - обіймають керівні посади офіщерського складу, 9136 - мають статус учасника бойових дій [17]. Отже, за даними Міністерства оборони України, за останні 10 років кількість жінок в армії збільшилась у 15 разів. Зміни в свідомості суспільства, які відбулися протягом останніх років стосовно гендерного питання в ЗСУ, спонукали до внесення змін до нормативно-правової бази: 2016 року - розширено перелік військових профресій для жінок, 2018 року - набув чинності Закон України «Про внесення змін до деяких законів України щодо забезпечення рівних прав та можливостей жінок і чоловіків під час проходження військової служби в Збройних Силах України та інших військових формуваннях», який зрівняв права жінок та чоловіків [18].

Статистика свідчить, що війна, нав'язана російським агресором, призвела до кардинальних і абсолютно реальних рефрорм в українській армії. Безпосередньо ці редрорми торкнулись питання гендеризації в ЗСУ, які раніше відрізнялися значною консервативністю в даному напрямі. Всі зміни, що останнім часом відбуваються в арміі, базуються на принципах гендеризащії структур НАТО та проходять у відповідності до Резолюції Ради Безпеки ООН № 1325 «Жінки, мир і безпека». Приєднавшись до вказаної Резолющії РБ, Україна прийняла «Національний план дій 3 виконання резолющії Ради Безпеки ООН 1325 «Жінки, мир, безпека» на період до 2020 року». Цей документ передбачає розширення участі жінок у вирішення військових конфрліктів [19].

Таким чином, 3 початком війни на Донбасі, жінки-військовослужбовці були снайперами, гранатометниками, кулеметниками, командирами БМП, розвідниками. Побачивши багатьох жінок на передовій у справі, військовослужбовці-чоловіки почали змінювати своє ставлення до них, «адже стало очевидним: українки готові і спроможні захищати Україну нарівні з чоловіками» [20]. Позитивну оцінку жінок-бійців в армії можна побачити i в книгах, що написані чоловіками - учасниками бойових дій на Сході, військовими кореспондентами [21]. Також не варто забувати і про той внесок у підтримку ЗСУ, що зробили жінки-волонтери, які від 2014 року всіма силами намагаються допомагати армії. 3 початком військових дій по всій Україні з'явились кулінарні, в'язальні сотні, групи «кікімор» по виготовленню маскувальних сіток та багато інших волонтерських об'єднань, організаторами та учасниками яких ставали жінки.

Водночас, слід зазначити, що відчутне збільшення жінок-військовослужбовців за останні роки, їх участь у російсько-українській війні, поступові зміни в законодавчій базі, направлені на зрівняння в правах жінок і чоловіків в армії не знімають багатьох болючих питань, що потребують подальшого вирішення: позбавлення стереотипного мислення, стосовно ролі та місця жінки в армії, як зі сторони суспільства в цілому так і самих жінок, що несуть військову службу; побутові питання, пов'язані з інфрраструктурою, яка пристосована під потреби чоловіків; відсутність або низький рівень можливостей обіймати керівні посади та приймати рішення.

Висновки і пропозиції. Отже, жінки від часів Першої світової війни до наших днів займають активну громадянську позищію, не залишаються осторонь військових конфліктів і завжди готові не лише допомагати, підтримувати військових-чоловіків, а й нарівні з ними проявляти звитягу, стійкість та мужність у захисті своєї Батьківщини. Це прагнення заслуговуе на підтримку як з боку держави так і суспільства в цілому, а також наукового переосмислення та розвитку комплексних досліджень. 


\section{Список літератури:}

1. Байдак М. Жінка в умовах війни у світлі повсякденних практик (на матеріалах Галичини 1914-1921 pp.) : автореф. дис. ... канд. іст. наук : 07.00.01. Львів, 2018. 22 c. URL: https://www.lnu.edu.ua/wp-content/uploads/ 2018/03/aref baidak.pdf (дата звернення: 22.02.2021).

2. Гук М. Жінки України в Першій світовій війні у сучасних вітчизняних дисертаційних дослідженнях. Часопис української історії. 2019. № 39. C. 104-113. URL: http://www.library.univ.kiev.ua/ukr/host/viking/db/ ftp/univ/chui/chui_2019_39.pdf (дата звернення: 21.02.2021).

3. Павлишин О. Емансипація жінки-селянки в роки Першої світової війни. «Бабська революція» 1918 р. у Східній Галичині. Украӥна модерна. Перша світова: украӥнська перспектива. 2016. № 23. С. $152-170$. URL:https://shron1.chtyvo.org.ua/Dudko_Oksana/Mizh_natsionalnoiu_i_populiarnoiu_kulturoiu_teatry_v_okupovanomu_ Lvovi_veresen_1914_roku_cherven_19.pdf? (дата звернення: 20.02.2021).

4. Стяжкіна О. В. Жінки України в повсякденні окупації: відмінності сценаріїв, інтенції й ресурси виживання. Український історичний журнал. 2015. № 2. C. 42-66. URL: https://core.ac.uk/download/pdf/87393653.pdf (дата звернення: 18.02.2021).

5. Шевченко М. Ю. Жіноцтво в окупованому Киеві (за матеріалами фондів Меморіального комплексу "Національний музей історії Великої Вітчизняної війни 1941-1945 років”). Архіви України. 2014. № 4-5. С. $256-273$. URL:http://www.irbis-nbuv.gov.ua/cgi-bin/irbis_nbuv/cgiirbis_64.exe?I21DBN=LINK\&P21DBN=UJRN\&Z21ID= $\& \mathrm{~S} 21 \mathrm{REF}=10 \& \mathrm{~S} 21 \mathrm{CNR}=20 \& \mathrm{~S} 21 \mathrm{STN}=1 \& \mathrm{~S} 21 \mathrm{FMT}=\mathrm{ASP}$ meta\&C21COM=S\&2_S21P03=FILA=\&2 S21STR=ay_2014_4-5_24 (дата звернення: 20.02.2021).

6. Суховерська I. I. Образ жінки в роки другої світової війни у сучасній російській історіографрії. Наукові праиі історичного фбакультету Запорізького національного університету. 2017. Вип. 49. С. $223-227$. URL:http://www.irbis-nbuv.gov.ua/cgi-bin/irbis_nbuv/cgiirbis 64.exe?I21DBN=LINK\&P21DBN=UJRN\&Z21ID= $\& \mathrm{~S} 21 \mathrm{REF}=10 \& \mathrm{~S} 21 \mathrm{CNR}=20 \& \mathrm{~S} 21 \mathrm{STN}=1 \& \mathrm{~S} 21 \mathrm{FMT}=\mathrm{ASP}$-meta\&C21COM=S\&2_S21P03=FILA=\&2_ S21STR=Npifznu_2017_49_44 (дата звернення: 18.02.2021).

7. Жінки Центральної та Східної Свропи у Другій світовій війні: гендерна специфіка досвіду в часи екстремального насильства : зб. наук. праць / за наук. ред. Г. Грінченко. Київ, 2015. 335 c. URL: https://ua.boell.org/ sites/default/files/zhinki_centralnoyi_ta_shidnoyi_ievropi_u_drugiy_svitoviy_viyni_-_genderna_specifika_ dosvidu_v_chasi_ekstremalnogo_nasilstva.pdf (дата звернення: 18.02.2021).

8. Гук М. С. Жінки України у Першій світовій війні: історіографрія : дис. ... канд. іст. наук : 07.00.01. Київ, 2020. 229 c. URL: https://shron1.chtyvo.org.ua/Huk_Mariia/Zhinky_Ukrainy_u_Pershii_svitovii_viini_istoriohrafiia.pdf ?PHPSESSID=91 gnufk2o352ar8m7m5v87vnn3 (дата звернення: 21.02 .2021 ).

9. Тітовська Ж. В. Діяльність Українських жіночих громадських об’еднань у роки Першої світової війни (1914-1917 рр.) : зб. наук. праць. Серія «Історія та географрія». Вип. 40. Харків, 2011. С. $23-26$. URL:http://www.irbis-nbuv.gov.ua/cgi-bin/irbis_nbuv/cgiirbis_64.exe?I21DBN=LINK\&P21DBN=UJRN\&Z21ID= $\& \mathrm{~S} 21 \mathrm{REF}=10 \& \mathrm{~S} 21 \mathrm{CNR}=20 \& \mathrm{~S} 21 \mathrm{STN}=1 \& \mathrm{~S} 21 \mathrm{FMT}=\mathrm{ASP}$.meta\& $21 \mathrm{COM}=\mathrm{S} \& 2 \_\mathrm{S} 21 \mathrm{P} 03=\mathrm{FILA}=\& 2$ S21STR=znpkhnpu_ist_2011_40_6 (дата звернення: 20.02.2021).

10. Смоляр Л. О. Минуле заради майбутнього. Жіночий рух Наддніпрянської України II пол. XIX - поч. XX ст. Сторінки історій. Одеса, 1998. 410 c. URL: https://uamoderna.com/images/biblioteka/Smoliar_books/Smoliar_ Mynule.pdf (дата звернення: 18.02.2021).

11. Світич К. С. Жіноча благодійність в сфері надання допомоги військовослужбовцям періоду Першої світової війни. Наукові записки Національного університету "Острозька акаделія". Серія "Гендерні дослідження". 2017. Вип. 3. С. 148-155. URL: http://www.irbis-nbuv.gov.ua/cgi-bin/irbis_nbuv/cgiirbis_64.exe?I21DBN=LIN $\mathrm{K} \& \mathrm{P} 21 \mathrm{DBN}=\mathrm{UJRN} \& Z 21 \mathrm{ID}=\& \mathrm{~S} 21 \mathrm{REF}=10 \& \mathrm{~S} 21 \mathrm{CNR}=20 \& \mathrm{~S} 21 \mathrm{STN}=1 \& \mathrm{~S} 21 \mathrm{FMT}=\mathrm{ASP}$ meta\&C21COM=S\&2_ S21P03=FILA=\&2_S21STR=nznuoagend_2017_3_19 (дата звернення: 19.02.2021).

12. Інтервю Кобалія А. з Бежук О. Жіночий досвід Першої світової, або галичанки в окопах Східного фрронту // Повага. Сайт кампанії проти сексизму в медіа і політиці. URL: https://povaha.org.ua/zhinochyj-dosvid-pershojisvitovoji-abo-halychanky-v-okopah-shidnoho-frontu/ (дата звернення: 20.02.2021).

13. Липовецький С. Жінка в мундирі. 100 років тому. Украӥнський тиждень. 2016. Березня 1. URL: https://tyzhden.ua/History/159715 (дата звернення: 20.02.2021).

14. Українські жінки в Другій світовій війні: декілька історій // Державна служба України у справах ветеранів війни та учасників антитерористичної операції: офіційний веб сайт. URL: http://dsvv.gov.ua/zvyazky-zhromadskistyu/spryyannya-rozvytku-hromadskoho-suspilstva/ukrajinski-zhinky-v-druhij-svitovij-vijni-dekilkaistorij.html (дата звернення: 21.02.2021).

15. Війна не робить винятків. Жіночі історії Другої світової // Громадський простір. URL: https://www.prostir.ua/ ?news=vijna-ne-robyt-vynyatkiv-zhinochi-istoriji-druhoji-svitvoji (дата звернення: 22.02.2021).

16. «Невидимий батальйон»: участь жінок у військових діях в АТО (соціологічне дослідження) / заг. ред. Тамари Марценюк. Київ : ФОП Клименко, 2016. 80 c. URL: http://ekmair.ukma.edu.ua/bitstream/handle/123456789/ 7746/Martsenyuk_Nevydymyi_bataloin.pdf?sequence=3\&isAllowed=y (дата звернення: 22.02.2021).

17. Нині у війську служить майже 30 тисяч жінок // Армія Inform. Інформаційне агентство. URL: https://cutt.ly/ Gvn8PvN (дата звернення: 22.02.2021).

18. Кількість жінок у нашому війську за десять років збільшилась у 15 разів // Міністерство оборони України: офіційний веб сайт. URL: https://www.mil.gov.ua/news/2019/09/17/kilkist-zhinok-u-nashomu-vijsku-za-desyatrokiv-zbilshilas-u-15-raziv/ (дата звернення: 22.02.2021).

19. Грабовська I. Сучасна українська жінка у війні із російським агресором // День. ТОВ «Українська Прес-група». URL: https://day.kyiv.ua/uk/blog/suspilstvo/suchasna-ukrayinska-zhinka-u-viyni-iz-rosiyskym-agresorom (дата звернення: 22.02.2021).

20. Про переоцінку ролі жінки в українському війську // Міністерство оборони України: офіційний веб сайт. URL: https://www.mil.gov.ua/diyalnist/genderni-pitannya-u-sferi-bezpeki/pro-pereoczinku-roli-zhinki-v-ukrainskomuvijsku.html (дата звернення: 22.02.2021).

21. Пророцтво Жанни. Історії українських воїнів / заг. ред. Валентина Буряченка. Київ : Військо України, 2018. 224 c. URL: https://www.mil.gov.ua/content/books/uxhVVb6Z3Z5KTKF4.pdf (дата звернення: 22.02.2021). 


\section{References:}

1. Baidak M. (2018) Zhinka v umovakh viiny u svitli povsiakdennykh praktyk (na materialakh Halychyny 1914-1921 rr.): avtoref. dys. ... kand. ist. nauk: 07.00.01. Lviv, 22 p. URL: https://www.lnu.edu.ua/wp-content/ uploads/2018/03/aref baidak.pdf (accessed 22 February 2021).

2. Huk M. (2019) Zhinky Ukrainy v Pershii svitovii viini u suchasnykh vitchyznianykh dysertatsiinykh doslidzhenniakh. Chasopys ukrainskoi istorii, no. 39, pp. 104-113. URL: http://www.library.univ.kiev.ua/ukr/host/viking/db/ ftp/univ/chui/chui_2019_39.pdf (accessed 21 February 2021).

3. Pavlyshyn O. (2016) Emansypatsiia zhinky-selianky v roky Pershoi svitovoi viiny. «Babska revoliutsiia» 1918 r. u Skhidnii Halychyni. Ukraina moderna. Persha svitova: ukrainska perspektyva, no. 23, pp. $152-170$. URL: https://shron1.chtyvo.org.ua/Dudko_Oksana/Mizh_natsionalnoiu_i_populiarnoiu_kulturoiu_teatry_v_okupovanomu_Lvovi_veresen_1914_roku_cherven_19.pdf? (accessed 20 February 2021).

4. Stiazhkina O. V. (2015) Zhinky Ukrainy v povsiakdenni okupatsii: vidminnosti stsenariiv, intentsii y resursy vyzhyvannia. Ukrainskyi istorychnyi zhurnal, no. 2, pp. 42-66. URL: https://core.ac.uk/download/pdf/87393653.pdf (accessed 18 February 2021).

5. Shevchenko M. Yu. (2014) Zhinotstvo v okupovanomu Kyievi (za materialamy fondiv Memorialnoho kompleksu "Natsionalnyi muzei istorii Velykoi Vitchyznianoi viiny 1941-1945 rokiv"). Arkhivy Ukrainy, no. 4-5, pp. 256-273. URL: http://www.irbis-nbuv.gov.ua/cgi-bin/irbis_nbuv/cgiirbis_64.exe?I21DBN=LINK\&P21DB$\mathrm{N}=\mathrm{UJRN} \& Z 21 \mathrm{ID}=\& \mathrm{~S} 21 \mathrm{REF}=10 \& \mathrm{~S} 21 \mathrm{CNR}=20 \& \mathrm{~S} 21 \mathrm{STN}=1 \& \mathrm{~S} 21 \mathrm{FMT}=\mathrm{ASP}$ meta\&C21COM=S\&2_S21P03=FILA=\&2_S21STR=ay_2014_4-5_24 (accessed 20 February 2021).

6. Sukhoverska I. I. (2017) Obraz zhinky v roky druhoi svitovoi viiny u suchasnii rosiiskii istoriohrafii. Naukovi pratsi istorychnoho fakultetu Zaporizkoho natsionalnoho universytetu, vol. 49, pp. $223-227$. URL:http://www.irbis-nbuv.gov.ua/cgi-bin/irbis_nbuv/cgiirbis_64.exe?I21DBN=LINK\&P21DBN=UJRN\&Z21ID= $\& \mathrm{~S} 21 \mathrm{REF}=10 \& \mathrm{~S} 21 \mathrm{CNR}=20 \& \mathrm{~S} 21 \mathrm{STN}=1 \& \mathrm{~S} 21 \mathrm{FMT}=\mathrm{ASP}$-meta\&C21COM=S\&2_S21P03=FILA=\&2_S21STR=Npifznu_2017_49_44 (accessed 18 February 2021).

7. Zhinky Tsentralnoi ta Skhidnoi Yevropy u Druhii svitovii viini: henderna spetsyfika dosvidu v chasy ekstremalnoho nasylstva: zb. nauk. prats / za nauk. red. H. Hrinchenko. Kyiv, 2015. 335 p. URL: https://ua.boell.org/sites/ default/files/zhinki_centralnoyi_ta_shidnoyi_ievropi_u_drugiy_svitoviy_viyni_-_genderna_specifika_dosvidu_v_ chasi_ekstremalnogo_nasilstva.pdf (accessed 18 February 2021).

8. Huk M. S. (2020) Zhinky Ukrainy u Pershii svitovii viini: istoriohrafiia: dys. ... kand. ist. nauk: 07.00.01. Kyiv, 229 p. URL:https://shron1.chtyvo.org.ua/Huk_Mariia/Zhinky_Ukrainy_u_Pershii_svitovii_viini_istoriohrafiia.pdf ?PHPSESSID=91gnufk2o352ar8m7m5v87vnn3 (accessed 21 February 2021).

9. Titovska Zh. V. (2011) Diialnist Ukrainskykh zhinochykh hromadskykh obiednan u roky Pershoi svitovoi viiny (1914 - 1917 rr.): zb. nauk. prats. Seriia "Istoriia ta heohrafiia», vol. 40. Kharkiv, pp. $23-26$. URL:http://www.irbis-nbuv.gov.ua/cgi-bin/irbis_nbuv/cgiirbis_64.exe?I21DBN=LINK\&P21DBN=UJRN\&Z21ID= $\& \mathrm{~S} 21 \mathrm{REF}=10 \& \mathrm{~S} 21 \mathrm{CNR}=20 \& \mathrm{~S} 21 \mathrm{STN}=1 \& \mathrm{~S} 21 \mathrm{FMT}=\mathrm{ASP}$ meta\&C21COM=S\&2_S21P03=FILA=\&2_S21STR= znpkhnpu_ist_2011_40_6 (accessed 20 February 2021).

10. Smoliar L. O. (1998) Mynule zarady maibutnoho. Zhinochyi rukh Naddniprianskoi Ukrainy II pol. XIX - poch. XX st. Storinky istorii. Odesa, 410 p. URL: https://uamoderna.com/images/biblioteka/Smoliar_books/Smoliar_ Mynule.pdf (accessed 18 February 2021).

11. Svitych K. S. (2017) Zhinocha blahodiinist v sferi nadannia dopomohy viiskovosluzhbovtsiam periodu Pershoi svitovoi viiny. Naukovi zapysky Natsionalnoho universytetu "Ostrozka akademiia". Seriia "Henderni doslidzhennia», vol. 3, pp. 148-155. URL: http://www.irbis-nbuv.gov.ua/cgi-bin/irbis_nbuv/cgiirbis_64.exe?I21DB$\mathrm{N}=\mathrm{LINK} \& \mathrm{P} 21 \mathrm{DBN}=\mathrm{UJRN} \& \mathrm{Z} 21 \mathrm{ID}=\& \mathrm{~S} 21 \mathrm{REF}=10 \& \mathrm{~S} 21 \mathrm{CNR}=20 \& \mathrm{~S} 21 \mathrm{STN}=1 \& \mathrm{~S} 21 \mathrm{FMT}=\mathrm{ASP}$ meta\&C 21COM=S\&2_S21P03=FILA=\&2_S21STR=nznuoagend_2017_3_19 (accessed 19 February 2021).

12. Interviu Kobaliia A. z Bezhuk O. Zhinochyi dosvid Pershoi svitovoi, abo halychanky v okopakh Skhidnoho frontu // Povaha. Sait kampanii proty seksyzmu v media i politytsi. URL: https://povaha.org.ua/zhinochyj-dosvid-pershoji-svitovoji-abo-halychanky-v-okopah-shidnoho-frontu/ (accessed 20 February 2021).

13. Lypovetskyi S. (2016. Bereznia 1) Zhinka v mundyri. 100 rokiv tomu. Ukrainskyi tyzhden. URL: https://tyzhden.ua/ History/159715 (accessed 20 February 2021).

14. Ukrainski zhinky v Druhii svitovii viini: dekilka istorii // Derzhavna sluzhba Ukrainy u spravakh veteraniv viiny ta uchasnykiv antyterorystychnoi operatsii: ofitsiinyi veb sait. URL: http://dsvv.gov.ua/zvyazky-z-hromadskistyu/ spryyannya-rozvytku-hromadskoho-suspilstva/ukrajinski-zhinky-v-druhij-svitovij-vijni-dekilka-istorij.html (accessed 21 February 2021).

15. Viina ne robyt vyniatkiv. Zhinochi istorii Druhoi svitovoi // Hromadskyi prostir. URL: https://www.prostir.ua/ ?news=vijna-ne-robyt-vynyatkiv-zhinochi-istoriji-druhoji-svitvoji (accessed 22 February 2021).

16. «Nevydymyi batalion»: uchast zhinok u viiskovykh diiakh v ATO (sotsiolohichne doslidzhennia) / zah. red. Tamary Martseniuk. Kyiv: FOP Klymenko, 2016.80 p. URL: http://ekmair.ukma.edu.ua/bitstream/handle/123456789/7746/ Martsenyuk_Nevydymyi_bataloin.pdf?sequence=3\&isAllowed=y (accessed 22 February 2021).

17. Nyni u viisku sluzhyt maizhe 30 tysiach zhinok // Armiia Inform. Informatsiine ahentstvo. URL: https://cutt.ly/ Gvn8PvN (accessed 22 February 2021).

18. Kilkist zhinok u nashomu viisku za desiat rokiv zbilshylas u 15 raziv // Ministerstvo oborony Ukrainy: ofitsiinyi vebsait.URL:https://www.mil.gov.ua/news/2019/09/17/kilkist-zhinok-u-nashomu-vijsku-za-desyat-rokiv-zbilshilasu-15-raziv/ (accessed 22 February 2021).

19. Hrabovska I. Suchasna ukrainska zhinka u viini iz rosiiskym ahresorom // Den. TOV «Ukrainska Pres-hrupa». URL: https://day.kyiv.ua/uk/blog/suspilstvo/suchasna-ukrayinska-zhinka-u-viyni-iz-rosiyskym-agresorom (accessed 22 February 2021).

20. Pro pereotsinku roli zhinky v ukrainskomu viisku // Ministerstvo oborony Ukrainy: ofitsiinyi veb sait. URL: https://www.mil.gov.ua/diyalnist/genderni-pitannya-u-sferi-bezpeki/pro-pereoczinku-roli-zhinki-v-ukrainskomu-vijsku.html (accessed 22 February 2021).

21. Prorotstvo Zhanny. Istorii ukrainskykh voiniv / zah. red. Valentyna Buriachenka. Kyiv: Viisko Ukrainy, 2018. 224 p. URL: https://www.mil.gov.ua/content/books/uxhVVb6Z3Z5KTKF4.pdf (accessed 22 February 2021). 